\title{
Evaluation of Risks Related to Transfer of Rural Housing Land for Tourism Development in the Context of "Separation of Three Rights" Reform in China
}

\author{
Ping Ren ${ }^{1}$, Buting Hong ${ }^{1,2} \&$ Siying $\mathrm{Zhu}^{1,2}$ \\ ${ }^{1}$ Key Laboratory of Land Resources Evaluation and Monitoring in Southwest of Ministry of Education, Sichuan \\ Normal University, Chengdu, Sichuan, China \\ ${ }^{2}$ Collaborative Innovation Center for Land Resource Development and Protection, Sichuan Normal University, \\ Chengdu, Sichuan, China \\ Correspondence: Ping Ren, Key Laboratory of Land Resources Evaluation and Monitoring in Southwest of \\ Ministry of Education, Sichuan Nornal University, Chengdu, Sichuan 610066, China. Tel: 86-028-8476-2198. \\ E-mail: pren121680@126.com
}

Received: November 17, 2021

Accepted: December 24, 2021

Online Published: January 15, 2022

doi:10.5539/jas.v14n2p24

URL: https://doi.org/10.5539/jas.v14n2p24

The research is financed by National Social Science Foundation of China (18XJY010).

\begin{abstract}
In this paper, based on a field survey on typical villages in a Chinese metropolis suburb, we employ a risk matrix and the Borda ranking method to evaluate risks related to transfer of rural housing land for tourism development from the perspectives of different stakeholders. We also make suggestions regarding how to standardize transfers and revitalize utilization of rural housing land use rights. Combining qualitative analysis and quantitative analysis, the risk matrix determines the various risk levels faced by different stakeholders in the circulation of rural housing land for tourism development from two dimensions: risk impact degree and risk occurrence probability. Then, the Borda ranking method can subdivide the risk types within each risk level, thus identifying the most critical risks. Our results indicate that (1) unfair distribution of income from land transfers is the major risk faced by farm households and directly decides their willingness to transfer their housing land; (2) market instability is the prime risk factor faced by social investors, and together with project progress risk, indirectly leads to occurrence of operation risk and severely affects the motivation of social investors to invest in transfer, development and operation of rural housing land for tourism development; (3) disappearance of countryside characteristics is the critical risk factor faced by village collectives, and coordination and management risk is the main impediment that blocks the process of transfer of rural housing land for tourism development; and (4) other risks confronted by stakeholders in land transfer, although not the main ones, still need to be granted great importance and followed up closely. Therefore, it is necessary not only to establish appropriate risk avoidance measures for different critical risk factors faced by different stakeholders of such land transfers, but also to strengthen study of the association between the risks, identify the conduction effect of direct and indirect risks, macro and micro risks, and before action and after action risks, and improve the ability to prevent and mitigate these risks.
\end{abstract}

Keywords: land management, separation of three rights reform, risk evaluation, risk matrix, transfer of rural housing land for tourism development, China

\section{Introduction}

In China, land is segmented into urban land and rural land, with each governed by significantly different systems of property rights (Cai, 2016; Song et al., 2020). Formally, urban land is owned by the state, whereas rural land is owned by village collectives (Zhu, 2017), which have adopted separate management rules, accordingly (Ho \& Lin, 2003). The land-use rights that urban and rural households have over their housing land are not equivalent (Rosato-Stevens, 2008; Wang et al., 2012; Wang et al., 2015). In rural China, each farm household, with an identity as a member of a village collective, is entitled to apply for a plot of housing land with a legal area free of charge to build a residential house and thus acquire the right to use the housing land. Meanwhile, rural housing 
land can only be circulated among village collective members and is forbidden to be traded on the open market. Fully transferrable rural housing land available to all farmers lacks efficient market mechanisms and policy support (Kong et al., 2018). Given its use characteristics and welfare guarantee functions such as one plot of housing land for one farm household, occupation and use for an unlimited long term, restricted usage and restricted circulation, rural housing land has become an essential institutional arrangement to guarantee the livelihood of farmers and security of rural China in the long run (Zhou et al., 2013; Yang et al., 2016; Guo et al., 2019; Yan et al., 2019).

As the course of urbanization and agricultural and rural modernization of China proceeds, a huge rural population has migrated to cities, leading to an increasingly prominent phenomenon of a significant area of rural housing land left abandoned and idle for a long time. Such uninhabited land this has scope to be utilized inefficiently or illegally circulated in hidden ways (Long et al., 2012; Liu et al., 2013; Zou et al., 2014; Gao et al., 2017), which sets rural China apart from the evolutionary characteristics of foreign villages (Smailes, 2002; García \& Ayuga, 2007). In particular, the property and asset functions of housing land have been neglected, both intentionally and unintentionally, and issues such as different rights and prices for the same land in urban and rural areas have been criticized by all sectors of society. China's existing housing land system has become more and more unfit to meet the country's social and economic development needs, and calls for housing land reform and revitalization of the right to use housing land are becoming increasingly loud. Although the debate in Chinese academia on circulation of the right to use rural housing land has never stopped (Li, 2008; Zhu et al., 2009; Song, 2016), related studies regarding rural housing land transfer have focused on institutional reforms, conflicts of interest among stakeholders, and transfer mechanisms and modes (Liu \& Li, 2013; Dang et al., 2016; Tian et al., 2017; Wang et al., 2017), the Chinese government has been taking a prudent attitude toward housing land reform given that it involves the interests of millions of farm households and the harmony and stability of rural society.

In 2015, China began to conduct experiment on requisition of rural land by allowing market trades of village collective construction land and enacting housing land system reforms in 33 counties (cities and districts) selected from across the country. With respect to housing land system reform, the pilot areas undertook bold explorations in acquisition, approval, and circulation of housing land use rights as well as paid-use and paid-exit on a voluntary and compensated basis from such rights. These efforts led to identification of numerous effective measures together with valuable experience that can be replicated and spread nationwide. Based on the experience obtained over three years of practice and exploration, in its No.1 Document released in 2018, the Central Committee of Chinese Communist Party (CCP) creatively initiated new reform arrangement to explore the "Separation of Three Rights" (ownership, qualification, and use rights) to rural housing land. Of these three rights, the ownership of rural housing land still belongs to village collectives, and this is an inherent requirement of the nature of public land ownership in China. Specifically, the right to have a qualification to use rural housing land is an independent right, which is separate from the use right and belongs to individual farmers who have an identity as a member of village collectives. As such, this right is the institutional foundation to protect farmer's interests and maintain social harmony in rural areas. The right to use rural housing land and houses built on such land can be transferred, subject to certain criteria, and this is of great significance to efficiently utilizing existing construction land in rural areas, increasing farm households' property incomes, stimulating rural development, and promoting the rural revitalization strategy currently being implemented in China. China's prudence and bottom-line thinking in terms of rural housing land system reform reflect the importance of risk control in the evolution of any such reforms. On one hand, risk usually varies from individual to individual. In the context of encouraging circulation of rural housing land, it is necessary to distinguish risks on the basis of stakeholders involved in the circulation of housing land to facilitate analysis of such risks in more details. On the other hand, general and qualitative analyses and prediction of risks are not sufficiently comprehensive because risks differ in the extent of their impact and probabilities. Therefore, it is necessary to verify risks quantitatively in combination with the implementation of relevant policies so as to precisely identify and control critical risks and provide a realistic basis for improving relevant policies and measures.

Rural tourism is an effective way to balance urban and rural development and implement China's rural revitalization strategy. According to the latest monitoring data provided by the Ministry of Agriculture and Rural Affairs of China, China's agritourism and rural tourism industry saw tourist numbers of more than 3.2 billion in 2019, earning an operation income exceeding 850 billion RMB Yuan and showing broad prospects for development. Under the guidance and support of relevant state polices, rural tourism based on rural housing land has become an important means to revitalize the right to use and asset functions of rural housing land and increase farmers' property incomes. Although regions with rich tourism resources have long used housing land 
for operation activities related to tourism, following the initiation of the "Separation of Three Rights" reform of rural housing land, standardization of housing land transfers for tourism development remains at an initial stage. In particular, external social capital is introduced through land leasing, equity and cooperative operations, and new participants of housing land transfers, such that subsequent development and operation may bring emergence of new problems and potential risks, which, if not properly controlled and prevented, will threaten the livelihood of farmers and the development and stability of rural society and its economy.

Focusing on revitalization and utilization of the right to use rural housing land and rural houses, this paper studies the circulation of rural housing land for tourism development. In this paper, we predict and analyze risks faced by various stakeholders involved in such circulation from the perspective of farm households (rural housing land qualification holders), social investors (ownership of the right to use rural housing land), and village collectives (owners of rural housing land). Through field investigations and a questionnaire survey, we evaluate and verify these risks quantitatively to identify critical risks faced by various stakeholders using a risk matrix and the Borda ranking method. Based on these identified risks, we propose measures and suggestions on risk avoidance and provide reference for decision-making regarding standardizing rural housing land circulation for tourism development, thereby facilitating the "Separation of Three Rights" reform of rural housing land and promoting coordinated and balanced development of rural tourism and rural revitalization.

\section{Predication of Risks Involved in Circulation of Rural Housing Land for Tourism Development}

In this paper, the circulation of rural housing land for tourism development refers to the transfer of all or part of the right to use rural housing land via forms such leasing, equity, or cooperative operation to other natural persons or enterprises for the purpose of rural tourism activities such as catering, accommodation, and cultural experiences without changing the ownership of the land. Participants involved in such transfer mainly include farm households, social investors, and village collectives. Because these participants play different roles and have different interests in the transfer process, the risks they face vary.

\subsection{Risks Faced by Farm Households}

(1) Risk of unfair distribution of income from a land transfer. The transfer of rural housing land for tourism development activates the earning function of rural housing land as an asset, and development of tourism activities introduces a substantial value-added space. In fact, farm households obtain only a very low amount of rent income. Despite a profit share proportion being agreed in equity or cooperative operation contracts, farm households usually cannot enjoy any or all of the added value created from tourism development due to a lack of special knowledge and information asymmetry. Unfair profit sharing in the process of rural housing land transfer is widespread (Sun, 2015).

(2) Risks in livelihood. Although the existing procedure for circulation of rural housing land and rural houses clearly stipulates that a certificate must be provided to show that housing has been made available to all rural households involved in the transfer of their land, the livelihood of these rural households is still threatened by factors such as unstable employment, incomes, and social security after their housing land is transferred (Zhu \& $\mathrm{Lu}, 2018$ ). In particular, farm households usually transfer their contracted farm land together with their housing land, and although they may obtain a considerable sum of compensation in the short term, they subsequently face significant uncertainty in terms of their livelihood. These potential livelihood risks make farm households hesitate to make a decision about transfer of their housing land and thus increases the time cost of coordination and communication among the participants of transfer-and that is before introducing the fact that some ask for an excessively high amount of compensation, making it difficult to realize such a transfer.

(3) Risks in living environment. Risks in the living environment are mainly faced by those farm households who transfer their housing land through a centralized residence, and find it difficult to adapt to the new neighborhood environment, are unsatisfied with the surrounding public service and production facilities, and feel a big psychological gap in comparison with their previous living environment of single-family houses (Sun et al., 2019).

(4) Risks of insufficient understanding of government policies. Some rural accommodation projects may involve situations where the hesitation of a small number of farm households may impede the entire project from proceeding. Under the pressure exerted by the investors, the village committee and other farm households who are willing to transfer their land might repeatedly persuade these hesitating farm households, who may be forced to transfer their housing land without fully understanding government policy and procedures (Liang \& Lin, 2019). This may lead to a lack of an effective guarantee of their legal rights and interests. 
(5) Risks of default by social investors. Tourism development operation activities require huge amount of investment and have a long payback period. Therefore, land transfer contracts for such activities generally have a long period and thus have great uncertainty. In particular, losses and even shutdown may occur for various reasons during operation, which makes it very likely that investors may breach the contract by failure to pay transfer fees in due time and thus cause damage to the interests of farm households.

\subsection{Risks Faced by Social Investors}

(1) Risks in project construction. In addition to farm households' hesitation and delays in signing land transfer agreement, factors such as complicated and time-consuming project approval procedures, failure to supply construction materials and labor in time, and slow progress in installing facilities such as water, electricity and gas supplies, and internet access may lead to failure to construct and operate the project as planned, causing great losses to investors.

(2) Operation risks. In the process of development, a tourism project will face great risks if it lacks support in respect of sales experience, market connections, and operation practice or even has insufficient financial resources to survive the period before it begins to be profitable. Moreover, to save costs, some investors only employ a very limited number of staff for the project, and one employee often has to do work of several job positions. The high labor intensity leads to rapid turnover of employees and difficulty continuing operations.

(3) Risks of market instability. The rural tourism market is hot and attracting an increasing number of investors. However, many of the investors fail to thoroughly analyze the essential background and market direction of rural tourism and are too optimistic about and expect too much from rural tourism. They do not have a clear idea about the needs of potential tourists. Against the background that rural tourism projects undergoing explosive development nationwide in China, tourists are divided spread thinly, and many similar projects are confronting problems such as intense homogeneous competition, short stay time of tourists, fewer regular customers, and uncertainty in tourist flow.

(4) Risks of default by farm households. Despite having signed a land transfer agreement with investors, farm households may breach the agreement due to lack of adequate policy and regulations on the circulation of housing land and, in particular, lack of an effective guarantee for their subsequent livelihood. In such cases, investors are usually the relatively weaker party and face great pressure and burdens in operation.

\subsection{Risks Faced by Village Collectives}

(1) Risks in coordination and management. As a result of the entry of social capital in the form of social investors, village collectives face increasing difficulties in coordination and management compared with the management mode needed in the previous society of acquaintances. Village collectives not only have to coordinate among various stakeholders to facilitate the deal, but also urge investors to pay transfer fees in a timely manner and monitor subsequent tourism development and operation activities after the deal is concluded. Due to the great difficulty in undertaking such management tasks, there may be violation acts that village collectives are unwilling to or dare not address.

(2) Risks of rural society instability. Against the background of vigorous rural tourism development, some villagers with relatively strong financial strength may operate agritainment resorts and farm accommodation, while some poorer villagers receive only a very small portion of their income from rural tourism by means of land transfer. This might further expand the gap between the rich and poor. In addition, a large number of tourists flowing into villages may also influence local security to a certain degree.

(3) Risks of vanishing countryside characteristics. Disappearance of countryside characteristics is the result of the invasion of modern urban lifestyles. Driven by economic benefits, some tourism operators transform original farm houses into bars, KTV, and other such uses to meet the need of tourists, thus changing the characteristic countryside culture and, to a certain extent, destroying the original local flavor and countryside features (Wu et al., 2013).

(4) Risks of destroying the rural ecology. In circumstances of increased rural tourism, most local land will be used for tourism-related activities, for example, crop land or idle land could be used as parking lots, leading to an imbalanced land utilization structure. As the number of tourists increases, domestic garbage and arbitrary discharge of sewage will also increase pollution and destroy the environment to different degrees.

Although they are classified by stakeholders, the above said risks can also be divided into direct and indirect risks, micro and macro risks, and before and after action risks, based on their impact and the stage at which they occur. For example, most risks faced by social capital/social investors seem irrelevant when simply considering the transfer of housing land for tourism development but are in fact indirect risks connected with the act of 
transferring. The conclusion of a transfer agreement is only a "nominal revitalization" of housing land, and whether the project will succeed and become an important channel to increase farm households' property income depends on subsequent tourism development and operation. The occurrence of these risks may not only lead to failure to effectively perform the agreement, but also, to a great degree, influence the activity of farm households to participate in land transfer and thus impede implementation of government policies. Therefore, the negative effect of indirect risks can never be neglected. In addition, the risks faced by village collectives are macro risks that primarily influence the local natural ecological environment and humanistic community, whereas those faced by farm households are micro ones that primarily influence individual farmers and their families.

\section{Method}

\subsection{Risk Matrix}

The risk matrix approach was first developed by the Electronic System Center of the US Air Force in April 1995 to assess the risk in the life cycle of purchase projects (Garvey \& Lansdowne, 1998). It is now a classic tool combining quantitative and qualitative analyses and is used to identify risk ratings from two dimensions, i.e., degree of impact and probability of occurrence (Markowski \& Mannan, 2008; Ni et al., 2010). This analysis method is simple and easy to use and can quickly identify critical risk factors. In this paper, we employ this method to evaluate the risks in circulation of rural housing land for tourism development in the surveyed area. The evaluation process is as follows: (1) values are assigned to related variables in accordance with responses in the effective questionnaire. Values ranging from 0 to 5 are assigned to different degrees of risk impact: "no impact," "weakly adverse," "mildly adverse," "averagely adverse," "severely adverse," and "extremely adverse." Values 1 and 0 are assigned to risk occurrence probabilities "yes" and "no", respectively; (2) the values assigned to variables are summed and averaged to determine the ratings of impact degree and occurrence probability according to the classification criteria in Table 1; and (3) the risk rating of housing land transfer for tourism development is finally determined based on the combination of the rating of impact degree and rating of probability (Table 2).

Table 1. Criteria for classification of ratings of impact degree and probability

\begin{tabular}{|c|c|c|c|c|c|}
\hline Risk impact degree & $\begin{array}{l}\text { Criteria of } \\
\text { classification }\end{array}$ & Implications & Risk probability & $\begin{array}{l}\text { Criteria of } \\
\text { classification }\end{array}$ & Implications \\
\hline Very severe & $(4,5]$ & $\begin{array}{l}\text { Occurrence of the risk will cause } \\
\text { great losses to the sufferer }\end{array}$ & Extremely high & $(0.9,1.0]$ & $\begin{array}{l}\text { Occurrence of risk is } \\
\text { extremely probable }\end{array}$ \\
\hline Rather severe & $(3,4]$ & $\begin{array}{l}\text { Occurrence of the risk will cause } \\
\text { rather great losses to the sufferer }\end{array}$ & Rather high & $(0.6,0.9]$ & $\begin{array}{l}\text { Probability of occurrence is } \\
\text { rather high }\end{array}$ \\
\hline Average & $(2,3]$ & $\begin{array}{l}\text { Occurrence of the risk will cause } \\
\text { average losses to the sufferer }\end{array}$ & Average & $(0.4,0.6]$ & $\begin{array}{l}\text { Risk may occur occasionally } \\
\text { or locally }\end{array}$ \\
\hline Rather mild & $(1,2]$ & $\begin{array}{l}\text { Occurrence of the risk will cause } \\
\text { rather mild losses to the sufferer }\end{array}$ & Rather low & $(0.1,0.4]$ & Risk may occur very seldom \\
\hline Very mild & {$[0,1]$} & $\begin{array}{l}\text { Occurrence of the risk will cause } \\
\text { very little losses to the sufferer }\end{array}$ & Very low & {$[0.0,0.1]$} & Risk will rarely occur \\
\hline
\end{tabular}

Table 2. Classifications of risk ratings of housing land transfer for tourism development

\begin{tabular}{llllll}
\hline \multirow{2}{*}{ Risk impact degree } & \multicolumn{5}{c}{ Risk probability } \\
\cline { 2 - 6 } & Very low & Rather low & Average & Rather high & Extremely high \\
\hline Very mild & Very low & Very low & Low & Average & Average \\
Rather mild & Very low & Low & Average & Average & High \\
Average & Low & Average & Average & High & High \\
Rather severe & Average & Average & High & High & Very high \\
Very severe & Average & High & High & Very high & Very high \\
\hline
\end{tabular}

\subsection{Borda Ranking Method}

The risk matrix intuitively shows risk ratings. However, there may exist many risk ties, which mean risk modules existing in the same risk rating that have roughly similar attributes and can be further subdivided. The existing of risk ties may make it difficult to effectively prioritize risk factors and thus hard to identify the most critical risk. 
By applying voting theory to the risk matrix, Lansdowne and Woodward (1996) proposed the Borda ranking method, by which the ranking values of risk impact degree and probability are calculated to convert qualitative risk ratings into Borda numbers and thus prioritize risks. A bigger Borda number indicates a lower Borda ranking value. The risk with the highest Borda number has a Borda ranking value of 0 , indicating that it is the most critical among all risks. The Borda number is calculated with the following formula:

$$
b_{i}=\sum\left(N-R_{i k}\right)
$$

where, $b_{i}$ represents the Borda number of risk $i ; N$ represents the total number of risks faced by different stakeholders, where according to the above analysis of risks faced by different stakeholders in the circulation of rural housing land for tourism development, there are five main risks faced by farmers, four main risks faced by social investors, and four main risks faced by village collectives, so $N=5,4$, and $4 ; k$ is a rule, i.e., $k=1$ indicates risk impact degree and $k=2$ indicates risk probability; $R_{i k}$ is the ranking value under rule $k$; and $R_{i l}$ and $R_{i 2}$ are calculated with the same method. For example, $R_{i 1}$ is calculated with the following formula:

$$
\begin{aligned}
R_{i 1} & =I_{j}=C_{j}+\left(1+M_{j}\right) / 2 \\
C_{j} & = \begin{cases}\sum_{r=1}^{j-1} M_{r} & (j \geq 2) \\
0 & (j=1)\end{cases}
\end{aligned}
$$

where, $j$ is the rating of risk impact degree, i.e., $j=\{1,2,3,4,5\}$ represents "very severe," "rather severe," "average," "rather mild," and "very mild," respectively; $I_{j}$ is the ranking value of risk impact degree rating $j$; and $M_{j}$ is the number of risk impact degree rating $j$.

\subsection{Study Area and Data Collection}

Following its approval in 2007 as a National Urban and Rural Integrated Support Reform Pilot Area, Chengdu (capital of Sichuan Province, China) has carried out a series of land management system reforms and innovation practices. After the "Separation of Three Rights" reform was initiated in 2018, some counties and districts of Chengdu successively began to explore the moderate relaxation of restrictions on circulation of the right to use rural housing land and rural houses. Among them, Pidu District and Qingbaijiang District, which are located in the suburban area of Chengdu, have set up an example for revitalizing and utilizing idle rural housing land and houses for tourism development. They combined rural housing land reform with a rural revitalization strategy, provided housing security while developing rural tourism, attracted arts, talent, and creation to rural areas, and utilized rural housing land to develop farm accommodation and leisure and health care industries.

During the period from July to October 2019, our research group successively carried out a field survey in Tongchun Village of Huayuan Town, Nongke Village, Qinghe Village, and Jintai Village of Youai Town, Anlong Village of Ande Town, Zhanqi Village of Tangchang Town, and Qinggangshu Village of Sandaoyan Town in Pidu District, and Minzhu Village, Ziku Village, Jinbu Village, Xinghua Village, and Xianfeng Village of Fuhong Town in Qingbaijiang District. A total of 270 questionnaires were randomly distributed through panel interviews and household interviews, and 262 valid questionnaires were returned for an effective return rate of $97 \%$. The respondents mainly included farm households, investors and management staff who develop tourism by utilizing rural housing land, village heads, secretaries of Chinese Communist Party village branches, and other front-line government personnel. Except for basic information on farm households, tourism operation development and local development information, the content of the questionnaire focused on risks that may be faced by the aforementioned stakeholders. Out of the 200 farm household respondents, 124 (64\%) have transferred their housing land for tourism development. The returned questionnaires were sorted and analyzed, and 186 were finally determined as valid, including 124 from farm household respondents (Table 3), 42 from social investor respondents, and 20 from village collective respondents. 
Table 3. Summary statistics of surveyed farm households

\begin{tabular}{|c|c|c|c|}
\hline Contents of the survey & Group & Number of farmers & Proportion $(\%)$ \\
\hline \multirow{2}{*}{ Gender } & Male & 89 & 71.77 \\
\hline & Female & 35 & 28.23 \\
\hline \multirow{5}{*}{ Age } & $18-30$ & 9 & 7.26 \\
\hline & $31-40$ & 15 & 12.10 \\
\hline & $41-50$ & 20 & 16.13 \\
\hline & $51-60$ & 42 & 33.87 \\
\hline & Over 60 & 38 & 30.65 \\
\hline \multirow{5}{*}{ Level of education } & Never attended school & 4 & 3.23 \\
\hline & Primary school & 36 & 29.03 \\
\hline & Junior high school & 56 & 45.16 \\
\hline & Senior middle school & 19 & 15.32 \\
\hline & Junior college or above & 9 & 7.26 \\
\hline \multirow{5}{*}{$\begin{array}{l}\text { Per capita annual household income } \\
\text { (in RMB Yuan) }\end{array}$} & Less than 10000 & 7 & 5.65 \\
\hline & $10,000-20,000$ & 70 & 56.45 \\
\hline & $20,000-30,000$ & 20 & 16.13 \\
\hline & $30,000-40,000$ & 13 & 10.48 \\
\hline & More than 40,000 & 14 & 11.29 \\
\hline & Agriculture only & 8 & 6.45 \\
\hline \multirow{3}{*}{ Sources of household income } & $\begin{array}{l}\text { Agriculture is the main source, } \\
\text { supplemented by non-agriculture }\end{array}$ & 23 & 18.55 \\
\hline & $\begin{array}{l}\text { Non-agriculture is the main source, } \\
\text { supplemented by agriculture }\end{array}$ & 55 & 44.35 \\
\hline & Non-agriculture only & 38 & 30.65 \\
\hline \multirow{4}{*}{ Housing land circulation period } & Within 5 years & 0 & 0.00 \\
\hline & $5-10$ years & 34 & 27.42 \\
\hline & $10-20$ years & 41 & 33.06 \\
\hline & More than 20 years & 49 & 39.52 \\
\hline \multirow{4}{*}{ Payment method of housing land circulation } & Payment on an annual basis & 44 & 35.48 \\
\hline & Lump sum & 56 & 45.16 \\
\hline & Dividend according to income & 24 & 19.35 \\
\hline & Others & 0 & 0.00 \\
\hline \multirow{2}{*}{ Satisfaction of income distribution } & Satisfied & 28 & 22.58 \\
\hline & Dissatisfied & 96 & 77.42 \\
\hline \multirow{3}{*}{ Circulation mode of housing land } & Determined through negotiation & 21 & 16.94 \\
\hline & Determined through intermediaries & 6 & 4.84 \\
\hline & Determined through village committee & 97 & 78.23 \\
\hline \multirow{4}{*}{ Problem solving method in circulation } & Determined through negotiation & 8 & 6.45 \\
\hline & Solving through village committee & 94 & 75.81 \\
\hline & Solving through Rural Property Rights Arbitration Court & 13 & 10.48 \\
\hline & Others & 9 & 7.26 \\
\hline \multirow{3}{*}{$\begin{array}{l}\text { Degree of understanding of policies } \\
\text { related to housing land circulation }\end{array}$} & Understand well & 29 & 23.39 \\
\hline & Understand a little & 51 & 41.13 \\
\hline & Have no idea & 44 & 35.48 \\
\hline
\end{tabular}

\section{Results}

From the evaluation results in Table 4, and taking the risks faced by farmers as an example, it shows that the impact degree of the risk of an unfair income distribution is rather severe, the occurrence probability of this risk is rather high, and the risk level is high. At the same time, the impact degree of a risk to their livelihood faced by farmers is very severe, and although the occurrence probability of this risk is rather low, the risk level is also high. Because both the risk of an unfair income distribution and the risk to livelihood are at a high level, it is impossible to determine which one of these two risks should be given greater priority and seen as a greater threat by the government from a qualitative point of view. However, the quantitative conversion and ranking of Borda value offers a way to make such a distinction, and accordingly, the results indicate that an unfair income distribution is the most critical risk faced by the farmers; the same is true for the evaluation results of the risks faced by other stakeholders. In the research case presented in this paper, the conversion and ranking of Borda values cannot completely distinguish between risk types that otherwise appeared to be tied or equally ranked, but 
it also allows for comparisons with previous qualitative evaluation results, although there is still a certain degree of improvement and optimization.

Table 4. Results of evaluation of risks in transfer of rural housing land for tourism development from different stakeholders

\begin{tabular}{|c|c|c|c|c|c|c|c|c|}
\hline \multirow[b]{2}{*}{ Subject } & \multirow[b]{2}{*}{ Type of risk } & \multicolumn{2}{|c|}{ Degree of impact } & \multicolumn{2}{|c|}{ Probability } & \multirow{2}{*}{$\begin{array}{l}\text { Risk } \\
\text { rating }\end{array}$} & \multirow{2}{*}{$\begin{array}{l}\text { Borda } \\
\text { number }\end{array}$} & \multirow{2}{*}{$\begin{array}{l}\text { Borda } \\
\text { ranking } \\
\text { value }\end{array}$} \\
\hline & & Rating & $\begin{array}{l}\text { Ranking } \\
\text { value }\end{array}$ & Rating & $\begin{array}{l}\text { Ranking } \\
\text { value }\end{array}$ & & & \\
\hline \multirow{5}{*}{ Farm household } & Unfair income distribution & Rather severe & 3 & Rather high & 1.5 & High & 5.5 & 0 \\
\hline & Livelihood & Very severe & 1.5 & Rather low & 4 & High & 4.5 & 1 \\
\hline & Insufficient understanding of policies & Rather mild & 5 & Rather high & 1.5 & Average & 3.5 & 2 \\
\hline & Default by social capital & Very severe & 1.5 & Very low & 5 & Average & 3.5 & 2 \\
\hline & Living environment & Average & 4 & Average & 3 & Average & 3 & 3 \\
\hline \multirow{4}{*}{ Social investor } & Market instability & Very severe & 1.5 & Rather high & 2.5 & Very high & 4 & 0 \\
\hline & Project construction & Average & 4 & Extremely high & 1 & High & 3 & 1 \\
\hline & Operation & Rather severe & 3 & Rather high & 2.5 & High & 2.5 & 2 \\
\hline & Default by farm households & Very severe & 1.5 & Rather low & 4 & High & 2.5 & 2 \\
\hline \multirow{4}{*}{ Village collective } & $\begin{array}{l}\text { Vanishing of countryside } \\
\text { characteristics }\end{array}$ & Very severe & 1.5 & Average & 2.5 & High & 4 & 0 \\
\hline & Coordination and management & Rather severe & 3.5 & Rather high & 1 & High & 3.5 & 1 \\
\hline & Destroying rural ecology & Very severe & 1.5 & Rather low & 4 & High & 2.5 & 2 \\
\hline & Instability of rural society & Rather severe & 3.5 & Average & 2.5 & High & 2 & 3 \\
\hline
\end{tabular}

\subsection{Evaluation Results and Analysis of Risks Faced by Farm Households}

From the perspective of farm households (Table 4), the risks include, first, the risk of an unfair distribution of income, with a rather severe impact and rather high probability of occurrence, has a high risk rating and is the major risk faced by farm households during the transfer of housing land for tourism development. Our survey found that more than $77 \%$ of farm households are unsatisfied with the distribution of income from their land transfer, and their concerns focus on the low income received from the land transfer. Although not fully reflecting the full reality of income distribution, their concerns have realistic foundations. According to local village officers, relevant government policies and documents stipulate that the district government and village collectives may collect a certain rate of land transfer income adjustment fees and housing land paid-use fees (including rent income fees) from social investors and farm households, depending on the mode of circulation of the housing land. However, in order to maximize the benefits for farm households and facilitate the transfer transactions, village collectives have not yet begun to collect any fees related to land transfers. Therefore, to a great extent, income from land transfers has been converted to income of land transfers available to farm households and therefore directly influences their willingness to transfer their housing land. Of the 76 surveyed farm households who had not transferred their housing land, 47\% refused the land transfer because the transfer fee did not meet their expectations. In addition, with respect to transfer fee payment method, only 24 farm households $(19 \%)$ chose a dividend from the tourism operation. This is a very small proportion of farm households and generally worry about the payment of dividend. The second type of risk is risk to livelihoods. Although this risk has a rather low probability of occurrence, it has a very severe degree of impact, making it rank among the main risk factors faced by farm households. In the surveyed district, rural tourism has developed sufficiently to exhibit trends of scale and aggregation. Various agritainment resorts and farm accommodations have a high demand for labor, and many farmers who have transferred their housing land chose to work in the rural tourism industry. Farming income accounts for a decreasing proportion of their total household income, with only $6 \%$ of farm households making a living purely from farming. To a great extent, the development of rural tourism has facilitated non-farming employment of local farm households; however, the operation situation of rural tourism activities also directly dictates the stability and sustainability of non-farming employment. Third, other risks have the same rating but somewhat differ. The risk of insufficient understanding of government policies has a rather high probability, suggesting that publicity of relevant policies could be improved. Risk of default by the social investor could potentially have a very severe impact on farm households but has a very low 
probability of occurrence. Both impact degree and probability of risk to the living environment are ranked as having an average level and are overall controllable.

\subsection{Evaluation Results and Analysis of Risks Faced by Social Investors}

From the perspective of social investors (Table 4), the risks include, first, the risk of market instability has a very severe impact and a rather high probability of occurrence, making it the primary risk factor faced by social investors. Investors who develop tourism through transfer of rural housing land and farm houses are most concerned about market activity and tourist flows, which are the prerequisite for earning early returns on their investment and making a profit. Nonetheless, our survey found that most rural tourism projects suffer from having a narrow focus on a single operation mode, mainly running farm restaurants, tea houses, and short-stay accommodation. These tourism projects face very intense homogenous competition and lack characteristic products integrated with local history, culture, customs, and ecology. As a result, tourist stay time is relatively short, and tourism operators generally complained about the tourist flow being lower than expected and facing great competition pressure. A great number of rural tourism projects represented by agritainment resorts are being operated throughout the surveyed districts, but these have dramatically different tourist flows. Some five-star or four-star agritainment resorts that opened earlier and have a large scale are crowded with tourists as a marketplace and occupy a large share of the local rural tourism market, whereas a great number of other small-scale agritainment resorts see few visits and struggle to break out of a vicious cycle of higher product prices, service quality much poorer than that of those star-level agritainment resorts, and severe employee turnover. This, to a certain extent, also contributes to the occurrence of operation risks. The second type of risk is project construction risk. This type of risk has an average degree of impact but an extremely high probability of occurrence, and thus is the main risk faced by social investors. Expenditures for land transfer fees and necessary supplies require huge capital outlays by operators in the initial stage. Therefore, tourism operators seek to open their business as quickly as possible. But delays in installation of facilities such as gas, water, and electricity supplies or internet access can severely delay the progress of furnishing and decoration works. Some operators responded that whereas the reconstruction of farm houses takes very little time and usually can be completed in five to six months, the installation of gas and internet is extremely slow and it might take more than a year before they can move in and formally open business. In addition, several village officers mentioned that "project approval procedure is very complicated, involves too many government departments and requires many official stamps being affixed, and sometimes lack of one stamp may delay the project for several months. We are all worried about that". This reflects that relevant support policies need to be further improved. The final risk is that of default by farm households. Because has a rather low probability of occurrence, it is not elaborated upon further here even though the degree of impact is very severe and risk rating is high. Nevertheless, measures should be taken to prevent and address such risk.

\subsection{Evaluation Results and Analysis of Risks Faced by Village Collective}

From the perspective of village collectives (Table 4), the risks include, first is the risk of disappearing countryside characteristics, which has a very severe degree of impact and average probability of occurrence, making it the critical risk factor faced by village collectives. A village's unique and characteristic residences, culture and customs are its identity. Erecting tourism advertisement signs, renovation and reconstruction of traditional farm houses, and construction of tourist facilities will unavoidably change the local countryside's features and the village environment. Villages that used to enjoy a quiet and peaceful rural production and living environment can find themselves suddenly facing a prevailing commercial atmosphere. However, as observed in the surveyed districts, operations represented by agritainment resorts are concentrated along the two sides of main road within villages, and rural features deeper in villages largely remain unchanged. On the one hand, village collectives proceed with housing land transfer and tourism development in an orderly way, following the principle of step by step: first one household, then another. Furthermore, most villages have developed a rural tourism plan, which emphasizes protection of countryside features and especially sets out strict approval and supervision procedures for renovation and reconstruction of transferred farm houses. These measures help ensure a low probability for the risk of destroying the rural ecological environment, and to a great extent, help ensure that the quality of local ecologic environment does not dramatically deteriorate. The second risk is the risks in coordination and management, which have a rather severe degree of impact and a rather high probability, making this type of risk another main risk faced by village collectives. In the process of rural housing land transfer for tourism development, village collectives largely play a role of a "middleman" and coordinator, in addition to carrying out relevant responsibilities according to law. In the surveyed districts, $78 \%$ of farm households and $60 \%$ of tourism business operators entrust village collectives with handling the transfer of housing land, and $76 \%$ of farm households and $86 \%$ of tourism business operators will seek help from village collectives in case of 
problems related to a land transfer. Because tourism development has certain requirements in terms of housing land plot locations, investors may be uninterested in some plots of housing land that farm households are willing to transfer, whereas other farm households could have investor interest in their land, but set too-high prices for their plots. Therefore, a mismatch can exist between supply and demand. In such cases, village collectives usually need to repeatedly communicate with and coordinate between the two sides, which imposes great work pressure and difficulty. The third risk is that of instability of rural society. This has a rather severe degree of impact, an average probability of occurrence, and a high risk rating. Therefore, attention shall be paid to it and cautions taken against such risk.

\section{Conclusions and Policy Implication}

In this paper, based on our field survey of typical villages in the suburban area of a Chinese metropolis, we evaluated and verified the risks arising in the circulation of rural housing land for tourism development from the perspectives of different stakeholders. The main conclusions are presented below:

(1) China's exploration and practice of the "Separation of Three Rights" reform meet rural China's current need for social and economic development. By completing the existing institutional system of housing land property rights, the establishment of a qualification to use rural land reduces farmers' risk of losing their land, provides a guarantee for orderly circulation of rural housing land, and supports the need for land to be used in rural construction and industrial development. Therefore, this policy will have a large effect in terms of implementation of China's rural revitalization strategy.

(2) Risks faced by farm households mainly include unfair distribution of incomes, livelihoods, and living environments, insufficient understanding of government policies, and default by social capital/social investors. Of these, unfair distribution of incomes is the biggest risk faced by farm households in the district we surveyed and directly influences a farm household's willingness to circulate their housing land.

(3) Risks faced by social capital and social investors mainly include project construction, operation, market instability risks, as well as default by farm households. Of these, market instability is the primary risk faced by tourism operators in the surveyed districts, together with risks in project construction. These risks in turn lead to operation risks and severely affect the initiative of social investors to participate in the circulation, development, and operation of housing land for tourism purposes.

(4) Risks faced by village collectives mainly include risks in coordination, management, instability of rural society, disappearance of countryside characteristics and destruction of the rural ecology. Of these, the disappearance of countryside characteristics is a critical but not outstanding risk factor faced by village collectives. Risks in coordination and management were common in the survey district and are the main factor that impedes circulation of housing land for tourism development.

(5) Other risks faced by participants, despite not being rated as critical according to the sequencing and not specifically observed in our survey, should still be given attention, followed up closely, avoided, and addressed in advance.

In order to standardize the circulation of housing land for tourism and subsequent development and operation, and based on the main risks faced by different stakeholders, we propose the following suggestions: First, it is recommended that a method to identify the qualification as a member of a village collective that is implementing "Separation of Three Rights" be explored and developed as soon as possible, along with a method to promote the confirmation, registration, and certification of qualification and right to use rural housing land, break the compound function of the right to use housing land, namely its residence security function and property income function, and separate the exercise of these two functions by qualification and right to use housing land. Second, we advise that lessons are gleaned from the experiences of developed regions to establish as soon as possible a housing land baseline price and farm house value assessment system appropriate to the local economic development and marketization level. In addition, we suggest establishing an income distribution mechanism for circulation of housing land for tourism development. The aim of such a mechanism is not only to increase the share of housing land transfer income distributed to farm households, but also to explore an effective path for farm households to share valued-added income earned from tourism development on the transferred housing land, improve farm households' activity and willingness to transfer their housing land and provide a guarantee of land use for rural revitalization. Third, it is advisable to develop a strict social capital entry system while also relaxing restrictions on market subjects that use housing land. In particular, in districts that are relatively saturated with rural tourism projects, emphasis shall be put on investigation of the credit status, financial strength, and planning and operation capabilities of social investors. In the preliminary project stage, social investors shall extensively investigate the market, identify their market position, provide innovative tourism products, attract 
and retain tourists with immersive consumption and high quality services, and avoid blind development of projects for quick success and homogenous competition. Finally, village collectives shall regularly inspect the development and construction activities occurring on transferred housing land and rural houses, supervise investors' tourism development and payment of transfer fees in strict accordance with the transfer contract and overall village and town plan, stop and report any illegal construction and/or destruction of the village's appearance or surrounding ecological environment, ensure balance and coordination between the circulation of housing land and rural tourism development, and vigorously facilitate rural revitalization considering the dimensions of economy, society, and ecology.

\section{Acknowledgements}

This work was supported by National Social Science Foundation of China [18XJY010].

\section{References}

Cai, M. N. (2016). Land for welfare in China. Land Use Policy, 55, 1-12. https://doi.org/10.1016/j.landusepol. 2016.03.014

Dang, S., Yuan, D. C., \& Kong, W. Y. (2016). Land cooperatives as an approach of suburban space construction: Under the reform of Chinese land transfer market. Frontiers of Architectural Research, 5(4), 425-432. https://doi.org/10.1016/j.foar.2016.09.002

Gao, X. S., Xu, A. Q., Liu, L., Deng, O. P., Zeng, M., Ling, J., \& Wei, Y. L. (2017). Understanding rural housing abandonment in China's rapid urbanization. Habitat International, 67, 13-21. https://doi.org/10.1016/j.habitatint.2017.06.009

García, A. I., \& Ayuga, F. (2007). Reuse of abandoned buildings and the rural landscape: The situation in Spain. Transactions of the ASABE, 50(4), 1383-1394. https://doi.org/10.13031/2013.23627

Garvey, P. R., \& Lansdowne, Z. F. (1998). Risk matrix: An approach for identifying, assessing, and ranking program risks. Air Force Journal of Logistics, 22, 18-21.

Guo, G. C., Li, X. Z., \& Wang, X. Y. (2019). Changes, dilemmas and prospects of the 70-year rural residential land institution in new China: An analytical framework. China Land Sciences, 33(12), 1-9.

Ho, S. P. S., \& Lin, G. C. S. (2003). Emerging land markets in rural land urban China: Policies and practices. The China Quarterly, 175, 681-707. https://doi.org/10.1017/s0305741003000407

Kong, X. S., Liu, Y. L., Jiang, P., Tian, Y. S., \& Zou, Y. F. (2018). A novel framework for rural homestead land transfer under collective ownership in China. Land Use Policy, 78, 138-146. https://doi.org/10.1016/ j.landusepol.2018.06.046

Lansdowne, Z. F., \& Woodward, B. S. (1996). Applying the Borda ranking method. Air Force Journal of Logistics, 20, 27-29.

Li, Y. N. (2008). The reform of the rural-urban dualism. Journal of Peking University(Philosophy and Social Sciences), 45(2), 5-11.

Liang, F. C., \& Lin, C. Y. (2019). Research on the risk evaluation and prevention measures of rural residential land withdrawal under different modes: A case study of Jinjiang City, Fujian Province. Research of Agricultural Modernization, 40(6), 1011-1020.

Liu, Y., \& Li, X. J. (2013). Game theory analysis on the generation process of transfer of rural construction land transfer. IERI Procedia, 5, 59-64. https://doi.org/10.1016/j.ieri.2013.11.070

Liu, Y. S., Yang, R., \& Li, Y. H. (2013). Potential of land consolidation of hollowed villages under different urbanization scenarios in China. Journal of Geographical Sciences, 23(3), 503-512. https://doi.org/10.1007/ s11442-013-1024-8

Long, H. L., Li, Y. R., Liu, Y. S., Woods, M., \& Zou, J. (2012). Accelerated restructuring in rural China fueled by 'increasing vs. decreasing balance' land-use policy for dealing with hollowed villages. Land Use Policy, 29(1), 11-22. https://doi.org/10.1016/j.landusepol.2011.04.003

Markowski, A. S., \& Mannan, M. S. (2008). Fuzzy risk matrix. Journal of Hazardous Materials, 159(1), 152-157. https://doi.org/10.1016/j.jhazmat.2008.03.055

Ni, H. H., Chen, A., \& Chen, N. (2010). Some extensions on risk matrix approach. Safety Science, 48(10), 1269-1278. https://doi.org/10.1016/j.ssci.2010.04.005 
Rosato-Stevens, M. (2008). Peasant land tenure security in China's transitional economy. Boston University International Law Journal, 26, 97-141.

Smailes, P. J. (2002). From rural dilution to multifunctional countryside: Some pointers to the future from South Australia. Australian Geographer, 33(1), 79-95. https://doi.org/10.1080/00049180220125024

Song, M. J., Wu, Y. L., \& Chen, L. (2020). Does the land titling program promote rural housing land transfer in China? Evidence from household surveys in Hubei Province. Land Use Policy, 97, 104701. https://doi.org/10.1016/j.landusepol.2020.104701

Song, Z. H. (2016). How to solve the dilemma of transferring land use right for farmers' housing in market. China Land Sciences, 30(5), 13-20.

Sun, F. (2015). Study on peasants' profit distribution in land transfer. International Business and Management, 11(2), 64-68. https://doi.org/10.3968/7620

Sun, P. F., Zhao, K., Zhou, S. Q., \& He, J. (2019). Risk expectation, social network and farmers' behavior of rural residential land exit: Based on 626 rural households' samples in Jinzhai County, Anhui Province. China Land Sciences, 33(4), 42-50.

Tian, L., Guo, X., \& Yin, W. (2017). From urban sprawl to land consolidation in suburban Shanghai under the backdrop of increasing versus decreasing balance policy: A perspective of property rights transfer. Urban Studies, 54(4), 878-896. https://doi.org/10.1177/0042098015615098

Wang, H., Wang, L. L., Su, F. B., \& Tao, R. (2012). Rural residential properties in China: Land use patterns, efficiency and prospects for reform. Habitat International, 36(2), 201-209. https://doi.org/10.1016/ j.habitatint.2011.06.004

Wang, H., Zhang, X. L., Wang, H. Z., \& Skitmore, M. (2017). The right-of-use transfer mechanism of collective construction land in new urban districts in China: The case of Zhoushan City. Habitat International, 61, 55-63. https://doi.org/10.1016/j.habitatint.2017.01.005

Wang, Q. X., Zhang, X. L., Wu, Y. Z., \& Skitmore, M. (2015). Collective land system in China: Congenital flaw or acquired irrational weakness? Habitat International, 50, 226-233. https://doi.org/10.1016/j.habitatint. 2015.08.035

Wu, G. C., Niu, X., \& Xu, H. Z. (2013). Study on land transfer risk evaluation during the development of rural tourism. Economic Geography, 33(3), 187-191.

Yan, J. M., Di, L. S. T., \& Xia, F. Z. (2019). The implementation of the rural revitalization strategy and the deepening of the reform of the 'Three Rights Separation' of rural homesteads. Reform, 1, 5-18.

Yang, R., Xu, Q., \& Long, H. L. (2016). Spatial distribution characteristics and optimized reconstruction analysis of China's rural settlements during the process of rapid urbanization. Journal of Rural Studies, 47, 413-424. https://doi.org/10.1016/j.jrurstud.2016.05.013

Zhou, G. H., He, Y. H, Tang, C. L., Yu, T., Xiao, G. Z., \& Zhong, T. (2013). Dynamic mechanism and present situation of rural settlement evolution in China. Journal of Geographical Sciences, 23(3), 513-524. https://doi.org/10.1007/s11442-013-1025-7

Zhu, P. X., Qu, F. T., \& Sun, W. D. (2009). Analysis on the equality and efficiency of rural residential land use right circulation. China Land Sciences, 23(5), 26-29.

Zhu, X. H. (2017). Impact of the household registration system on farmers' rural housing land use decisions in China. Land, 6(4), 75. https://doi.org/10.3390/land6040075

Zhu, X. H., \& Lu, S. X. (2018). Risk perception, ability of resisting risk and farmer willingness to exit rural housing land. Resources Science, 40(4), 698-706.

Zou, Y. H., Zhao, W. X., \& Mason, R. (2014). Marketization of collective-owned rural land: A breakthrough in Shenzhen, China. Sustainability, 6(12), 9114-9123. https://doi.org/10.3390/su6129114

\section{Copyrights}

Copyright for this article is retained by the author(s), with first publication rights granted to the journal.

This is an open-access article distributed under the terms and conditions of the Creative Commons Attribution license (http://creativecommons.org/licenses/by/4.0/). 